\title{
A Low-Temperature Heat Output Photoactive Material-Based High-Performance Thermal Energy Storage Closed System
}

\author{
Xiangyu Yang ${ }^{1,2}$, Shijie Li $^{2}$, Jin Zhang ${ }^{2}$, Xiaomin Wang ${ }^{1}$, Yongzhen Wang ${ }^{1, *}$ and Jianguo Zhao ${ }^{1,2, *}$ \\ 1 College of Materials Science and Engineering, Taiyuan University of Technology, Yingze West Street, \\ Taiyuan 030024, China; yangxiangyu0039@link.tyut.edu.cn (X.Y.); wangxm62@126.com (X.W.) \\ 2 Institute of Carbon Materials Science, Shanxi Datong University, Xingyun Street, Datong 037009, China; \\ li841974@sina.com (S.L.); zhangjin50@hrbeu.edu.cn (J.Z.) \\ * Correspondence: wangyz62@163.com (Y.W.); zhaojianguo@sxdtdx.edu.cn (J.Z.)
}

Citation: Yang, X.; Li, S.; Zhang, J.; Wang, X.; Wang, Y.; Zhao, J. A Low-Temperature Heat Output Photoactive Material-Based High-Performance Thermal Energy Storage Closed System. Materials 2021, 14, 1434. https://doi.org/ 10.3390/ma14061434

Academic Editor: Mariano Palomba

Received: 27 December 2020

Accepted: 25 February 2021

Published: 16 March 2021

Publisher's Note: MDPI stays neutral with regard to jurisdictional claims in published maps and institutional affiliations.

Copyright: (c) 2021 by the authors. Licensee MDPI, Basel, Switzerland. This article is an open access article distributed under the terms and conditions of the Creative Commons Attribution (CC BY) license (https:// creativecommons.org/licenses/by/ $4.0 /)$.

\begin{abstract}
Designing and synthesizing photothermal conversion materials with better storage capacity, long-term stability as well as low temperature energy output capability is still a huge challenge in the area of photothermal storage. In this work, we report a brand new photothermal conversion material obtained by attaching trifluoromethylated azobenzene $\left(\mathrm{Azo}_{\mathrm{F}}\right)$ to reduced graphene oxide (rGO). Azo F $^{-} \mathrm{GO}$ exhibits outstanding heat storage density and power density up to $386.1 \mathrm{~kJ} \cdot \mathrm{kg}^{-1}$ and $890.6 \mathrm{~W} \cdot \mathrm{kg}^{-1}$, respectively, with a long half-life $(87.7 \mathrm{~h})$ because of the H-bonds based on high attachment density. Azo $-\mathrm{rGO}$ also exhibits excellent cycling stability and is equipped with lowtemperature energy output capability, which achieves the reversible cycle of photothermal conversion within a closed system. This novel $\mathrm{Azo}_{\mathrm{F}}-\mathrm{rGO}$ complex, which on the one hand exhibits remarkable energy storage performance as well as excellent storage life span, and on the other hand is equipped with the ability to release heat at low temperatures, shows broad prospects in the practical application of actual photothermal storage.
\end{abstract}

Keywords: photothermal conversion material; outstanding heat storage density; long-term storage; low temperature energy output; closed system

\section{Introduction}

With the fast development of society, people's demand for energy is increasing and the energy issue has now become one of the major problems that human beings need to deal with [1]. Solar energy has the advantages of sufficient reserves, no pollution and economical availability. Efficiently converting and storing solar energy has become an important way to overcome the current energy shortage crisis [2-5]. Recently, photothermal conversion materials have attracted extensive attention as a new method for storing solar energy [6]. Photothermal conversion materials can store solar energy in chemical bonds through photo-isomerization of units and then releasing the stored energy as thermal energy when exposed to different external stimulus, achieving photothermal conversion within a closed system. Such materials are able to effectively convert light energy into its own chemical bonds and release its stored energy while avoiding the emission of additional greenhouse gases, with the potential to achieve low-cost and large-scale industrial solar storage [7]. However, photothermal conversion materials still have the shortcomings of short storage time, low energy density and inability to achieve energy release under low temperatures, which are key factors limiting its practical application in solar thermal energy storage $[8,9]$.

Owing to its special photoisomerization ability, good structural stability and controllable configuration recoverability, azobenzene and its derivatives with numerous applications $[10,11]$ has received extensive research interest as a kind of photothermal conversion material $[12,13]$. However, due to the disadvantages of poor storage performance and storage half-life $\left(\tau_{1 / 2}\right)$ arising from low isomerization enthalpy $(\Delta H)$, azobenzene did not 
exert its full potential in terms of photothermal conversion and storage [14]. To override the above hurdles, great efforts have been made on the basis of molecular design by introducing different substituents and increasing the interaction between molecules [15-17]. Grossman et al. [18] reported azobenzene derivatives with bulky aromatic groups as photoactive chemical heat storage materials. Owing to the introduction of bulky phenyl groups, the solid-state azobenzene derivatives not only improve the energy density but also improve the corresponding thermal stability. Bléger et al. [19] reported $o$-Fluoroazobenzenes and derivatives which exhibit an unprecedented long half-life owing to the ortho-fluorine substituent which reduces electron density around the $-\mathrm{N}=\mathrm{N}-$ double bond. Despite great efforts having been made, it is still an intractable problem to apply azobenzene photothermal conversion material to practical energy storage.

Different from freely dispersed azobenzene, many azobenzene carbon materials were formed by introducing azobenzene into high-strength carbon nanomaterials forms many azobenzene carbon nanocomposites $[7,20,21]$ accompanied by a more closely ordered structure, which have excellent storage capacity and life cycle. The templated, structure modified azobenzene enhance the intermolecular interactions while obtaining a more stable and tightly ordered structure, which jointly improved the storage capacity of azobenzene carbon materials [22,23]. In addition, because of the unique 2D structure and broad surface of graphene with numerous applications $[24,25]$ which contributes to high attachment density, the templated azobenzene/graphene nanomaterials show broad prospects in photothermal storage [26]. Unfortunately, azobenzene carbon nanomaterials still have problems such as difficulty in releasing storage heat at low temperatures and the inability to balance energy density and half-life, which limits their further practical application $[27,28]$. Therefore, how to simultaneously achieve the improvement of storage capacity and life cycle with low-temperature energy output capability is still a key issue in current research.

In this work, we report a novel photothermal conversion material by attaching trifluoromethylated azobenzene $\left(\mathrm{Azo}_{\mathrm{F}}\right)$ to reduced graphene oxide $(\mathrm{rGO})$. The storage capacity and storage life span as well as the cycling stability performance of $\mathrm{Azo}_{\mathrm{F}}-\mathrm{rGO}$ has made great progress. $\mathrm{Azo}_{\mathrm{F}}-\mathrm{rGO}$ exhibits great development potential in recyclable and long term photothermal storage.

\section{Materials and Methods}

\subsection{Materials}

3-amino-5-(trifluoromethyl)benzoic acid (99\%), 3,5-dimethoxyaniline (99\%), sodium nitrite $(97 \%), \mathrm{Na}_{2} \mathrm{CO}_{3}(97 \%)$ and $\mathrm{NaBH}_{4}(97 \%)$ were purchased from Aladdin Reagent (Shanghai, China).

\subsection{Detailed Synthesis Steps}

- 3-amino-5-(trifluoromethyl)benzoic acid (1.025 g) was dissolved in the $\mathrm{HCl}$ solution $\left(50 \mathrm{~mL}, 0.5 \mathrm{~mol} \cdot \mathrm{L}^{-1}\right)$, then $\mathrm{NaNO}_{2}(0.380 \mathrm{~g})$ was added and reacted at ice bath for $80 \mathrm{~min}$. After dissolving 3,5-dimethoxyaniline $(0.765 \mathrm{~g})$ in water, we slowly added the above mixture to it, adjusted the $\mathrm{pH}$ to 7 and reacted it in an ice bath for $4 \mathrm{~h} . \mathrm{Azo}_{\mathrm{F}}$ was obtained after further purification $(1.255 \mathrm{~g}, 68 \%)$.

- $\mathrm{GO}$ was synthesized according to the literature reports [29]. First, we used $\mathrm{NaOH}$ $\left(1 \mathrm{~mol} \cdot \mathrm{L}^{-1}\right)$ solution to change the $\mathrm{pH}$ of the $\mathrm{GO}$ aqueous solution $\left(300 \mathrm{~mL}, 0.5 \mathrm{mg} \cdot \mathrm{mL}^{-1}\right.$ ) to 10 , then we reacted it at $90^{\circ} \mathrm{C}$ for $4 \mathrm{~h}$ with $\mathrm{NaBH}_{4}(180 \mathrm{mg})$ under $\mathrm{N}_{2}$ atmosphere. When the reaction was complete, $\mathrm{rGO}$ was obtained by washing the mixture with water multiple times.

- $\quad \mathrm{Azo}_{\mathrm{F}}(0.738 \mathrm{~g})$ was dissolved in the $\mathrm{HCl}$ solution $\left(60 \mathrm{~mL}, 0.5 \cdot \mathrm{mol} \mathrm{L}^{-1}\right)$, then $\mathrm{NaNO}_{2}$ $(0.141 \mathrm{~g})$ was slowly added and reacted in an ice bath for $80 \mathrm{~min}$, and the above mixture was slowly added to the rGO solution $\left(62 \mathrm{~mL}, 1 \mathrm{mg} \cdot \mathrm{mL}^{-1}\right)$. The mixture was first reacted at $0{ }^{\circ} \mathrm{C}$ for $4 \mathrm{~h}$ and then at $30^{\circ} \mathrm{C}$ for $16 \mathrm{~h}$. Azo $\mathrm{F}_{\mathrm{F}}-\mathrm{rGO}$ was obtained by purifying the mixture with water and DMF multiple times. 


\subsection{Characterizations}

The FT-IR was gathered from Vertex 70 (Bruker, Karlsruhe, Germany). The XRD was gathered from X'Pert Pro MPD (PANalytical, Almelo, Holland). Raman spectrum was gathered from LabRAM Aramis (HORIBA, Paris, France). The XPS was gathered from ESCALAB 250Xi (ThermoFisher, Waltham, MA, USA) using C1 s $=284.8 \mathrm{eV}$ for energy calibration procedures, Operation Mode:CAE:Pass Energy 100.0 Ev, software:Thermo Avantage 5.976 and hemispherical energy analyzer were used for the test, the test vacuum was $5 \times 10^{-9}$ Torr, the sample was fixed on the sample stage with conductive glue, the background was buckled through the smart method, and the energy calibration was performed with gold, silver and copper. The TGA was performed on STA449F5 (NETZSCH, Bavaria, Germany). TEM was gathered from Tecnai F20 (FEI, Hillsboro, Oregon, USA). SEM were gathered from SU8010 (Hitachi, Tokyo, Japan). The UV-Vis absorption spectra was performed on SPECORD 50 PLUS (ANALYTIK JENA, Jena, Germany) in the range of $250 \sim 550 \mathrm{~nm}$ with the resolution of $0.1 \mathrm{~nm}$. The trans $\rightarrow$ cis transition was introduced by a multiband LED lamp at $365 \mathrm{~nm}$. The cis $\rightarrow$ trans transition was introduced by a multiband LED lamp at $540 \mathrm{~nm}$. The light intensity was gathered from an optical power meter (PLMW2000, Bofeilai Technology, Beijing, China). The heat storage density was determined through differential scanning calorimetry (DSC, 214 Polyma, NETZSCH, Bavaria, Germany) under $\mathrm{N}_{2}$.

\section{Results and Discussion}

\subsection{Chemical Structure}

As shown in Figure 1a, the low-resolution TEM image of rGO exhibited a smooth structure and its electron diffraction exhibited a hexagonal lattice according to Fast Fourier Transform (FFT) patterns within Figure 1b, demonstrating its good crystallinity. Figure 1c shows that the surface of the material became rough, and the electron diffraction spot of $\mathrm{Azo}_{\mathrm{F}}-\mathrm{rGO}$ (Figure 1d) has become a closed loop attributed to the adhesion of $\mathrm{Azo}_{\mathrm{F}}$ on rGO [30,31]. Furthermore, the SEM of $\mathrm{Azo}_{\mathrm{F}}-\mathrm{rGO}$ (Figure 1f) shows a stacking phenomenon compared with rGO (Figure 1e). This phenomenon not only reduced the distance between adjacent graphene layers but also enhanced the intermolecular interaction, resulting in a growth in the storage capacity as well as $\tau_{1 / 2}$ of $\mathrm{Azo}_{\mathrm{F}}-\mathrm{rGO}$ [21]. In addition, it can also be concluded that the distance between layers was reduced based on the XRD results (Figure S2). After the reduction of GO, the $\left(\begin{array}{lll}0 & 0 & 1\end{array}\right)$ diffraction peak at $11.3^{\circ}$ disappeared [32] and was replaced by the $\left(\begin{array}{ll}0 & 0\end{array}\right)$ diffraction peak at $22.9^{\circ}$ of $\mathrm{rGO}$, and the corresponding grain size was $25.51 \mathrm{~nm}$ based on Scherrer formula [33]. After attaching Azo $\mathrm{F}_{\mathrm{F}}$ onto rGO, the $2 \theta$ of $\mathrm{Azo}_{\mathrm{F}}-\mathrm{rGO}$ has become to $25.2^{\circ}$ with the grain size of $22.63 \mathrm{~nm}$, which is consistent with the SEM observation (Figure 1f) [34].

The $\mathrm{Azo}_{\mathrm{F}}-\mathrm{rGO}$ had new peaks of $-\mathrm{N}=\mathrm{N}-\left(1430 \mathrm{~cm}^{-1}\right)$ and $-\mathrm{CF}_{3}\left(1140 \mathrm{~cm}^{-1}\right)$ compared to $\mathrm{rGO}$ [35] according to Figure 2a. Moreover, the FT-IR spectra of $\mathrm{Azo}_{\mathrm{F}}-\mathrm{rGO}$ and $\mathrm{Azo}_{\mathrm{F}}$ also showed peaks derived from $-\mathrm{OH}\left(3298 \mathrm{~cm}^{-1}\right)$ and $-\mathrm{C}=\mathrm{O}\left(1640 \mathrm{~cm}^{-1}\right)$. It can also be seen from Figure $2 \mathrm{a}$ that the wavenumbers of $-\mathrm{OH}$ and $-\mathrm{C}=\mathrm{O}$ of $\mathrm{Azo}_{\mathrm{F}}-\mathrm{rGO}$ show a significant red shift compared to that of $\mathrm{AzO}_{\mathrm{F}}\left(3204 \mathrm{~cm}^{-1}\right.$ and $\left.1700 \mathrm{~cm}^{-1}\right)$, confirming the formation $\mathrm{H}-\mathrm{bond}$ of $\mathrm{Azo}_{\mathrm{F}}$ on $\mathrm{rGO}$ [36]. XPS results also proven the successful grafting of $\mathrm{Azo}_{\mathrm{F}}$ on rGO. In addition, the characteristic peaks of $\mathrm{AzO}_{\mathrm{F}}$ at $287.5 \mathrm{eV}$ and $292.5 \mathrm{eV}$ corresponding to $\mathrm{C}-\mathrm{N}$ and $\mathrm{C}-\mathrm{F}$ bond also appeared in $\mathrm{Azo}_{\mathrm{F}}-\mathrm{rGO}$ (Figure S3) [35]. Additionally, the fact that there were characteristic peaks of $-\mathrm{N}=\mathrm{N}-(400.3 \mathrm{eV})$ and $-\mathrm{CF}_{3}(688.3 \mathrm{eV})$ in $\mathrm{Azo}_{\mathrm{F}}-\mathrm{rGO}$ also confirmed the successful bonding between $\mathrm{Azo}_{\mathrm{F}}$ and $\mathrm{rGO}$ [35]. 


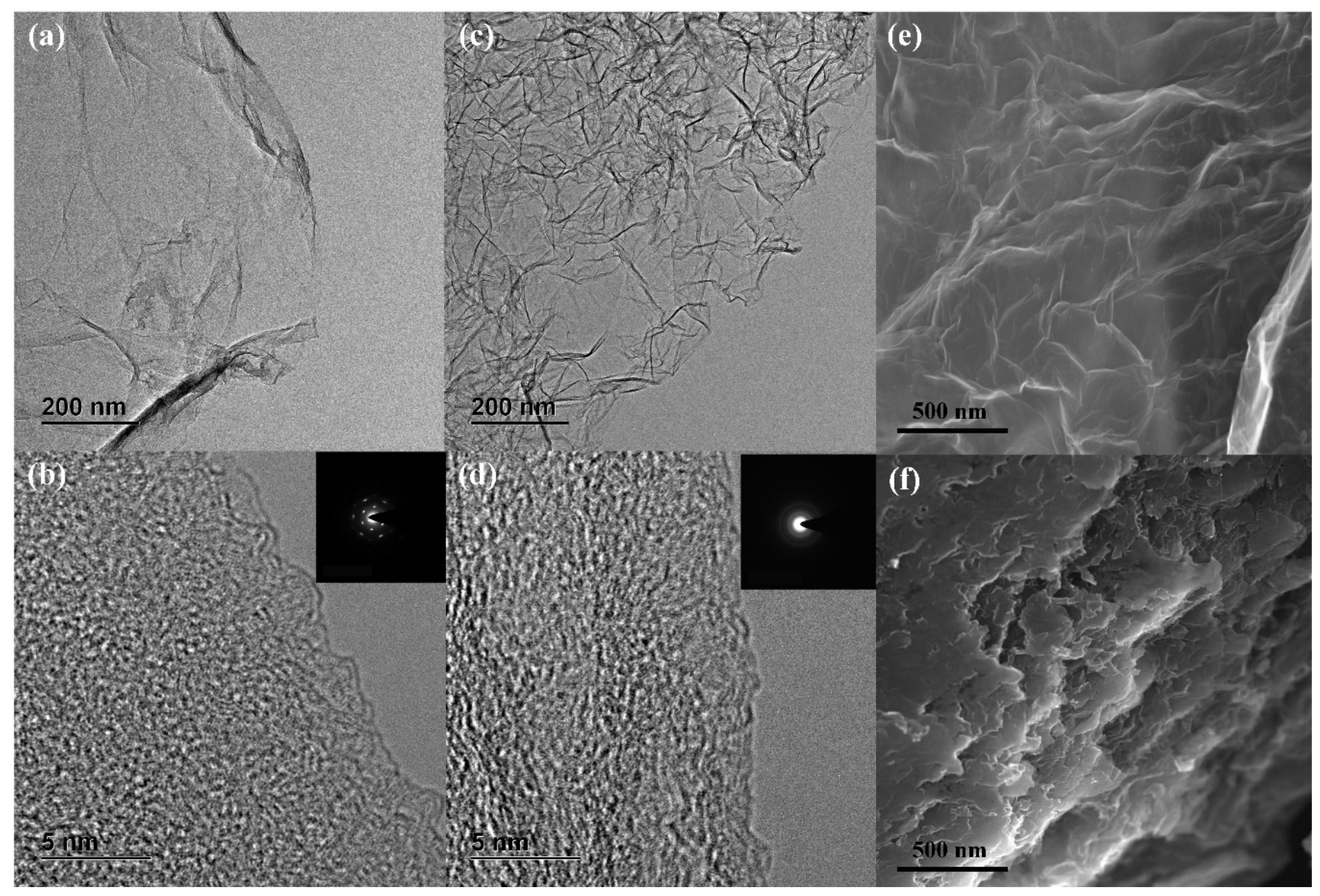

Figure 1. $(\mathbf{a}, \mathbf{c})$ Low resolution TEM images of $\mathrm{rGO}$ and $\mathrm{Azo}_{\mathrm{F}}-\mathrm{rGO},(\mathbf{b}, \mathbf{d})$ high resolution TEM images of $\mathrm{rGO}$ and $\mathrm{Azo} \mathrm{F}_{\mathrm{F}}-\mathrm{rGO}$ with FFTs, and SEM images of (e) rGO and (f) Azo - rGO.

The high-density adhesion of $\mathrm{Azo}_{\mathrm{F}}$ onto rGO nanosheets is inextricably linked to the improvement of the performance of $\mathrm{Azo}_{\mathrm{F}}-\mathrm{rGO}$. The decomposition of $\mathrm{rGO}$ during the whole heating process was linear according to Figure $2 \mathrm{~d}$, and its weight loss mainly attributed to the disappearance of oxygen-containing groups [37]. The $\mathrm{Azo}_{\mathrm{F}}$ was stable before $185^{\circ} \mathrm{C}$, and its weight loss was attributed to self-decomposition. Additionally, the weight loss of $\mathrm{Azo}_{\mathrm{F}}-\mathrm{rGO}$ was caused by the weight loss of $\mathrm{Azo}_{\mathrm{F}}$ and $\mathrm{rGO}$ [27]. Therefore, the attachment density $\left(\mathrm{A}_{\mathrm{d}}\right)$ of $\mathrm{Azo}_{\mathrm{F}}$ on $\mathrm{rGO}$ after different time reactions can be obtained based on Equation (1) [38].

$$
D_{g}=\frac{R_{p}-R}{R_{p}-R_{a}} \times 100 \%
$$

where $R a$ is the residual weight percentage of $\mathrm{Azo}_{\mathrm{F}}, R$ is the residual weight percentage of $\mathrm{Azo}_{\mathrm{F}}-\mathrm{rGO}, R p$ is the residual weight percentage of $\mathrm{rGO}$.

Table 1 shows that the attachment density $\left(A_{d}\right)$ was $1 / 40$ after the first reaction and increased to $1 / 16$ after the third reaction. The attachment density can also be obtained based on XPS [39]. It can also be seen from Table 1 that the results obtained by XPS and TGA were almost identical. From the above results, it can be concluded that almost every 16 carbon atoms of rGO correspond to one $\mathrm{Azo}_{\mathrm{F}}$ after the third reaction, which is better than previous research $[21,40]$. High adhesion density on the one hand helps to form intermolecular hydrogen bonds, while on the other hand it also enhances intermolecular interactions, which improves the storage performance of Azo $_{\mathrm{F}}-\mathrm{rGO}$ [41]. In addition, Raman spectroscopy also proved this result. It can also be seen from Figure $\mathrm{S} 4$ that the $\mathrm{I}_{\mathrm{D}} / \mathrm{I}_{\mathrm{G}}$ value of $\mathrm{Azo}_{\mathrm{F}}-\mathrm{rGO}-1$ (1.14) and $\mathrm{Azo}_{\mathrm{F}}-\mathrm{rGO}-3$ (1.18) was much larger than $\mathrm{rGO}(1.08)$, 
which indicates that the crystal structure of rGO has changed after attachment [31], proving the remarkable attachment density of $\mathrm{Azo}_{\mathrm{F}}$ on $\mathrm{rGO}$.
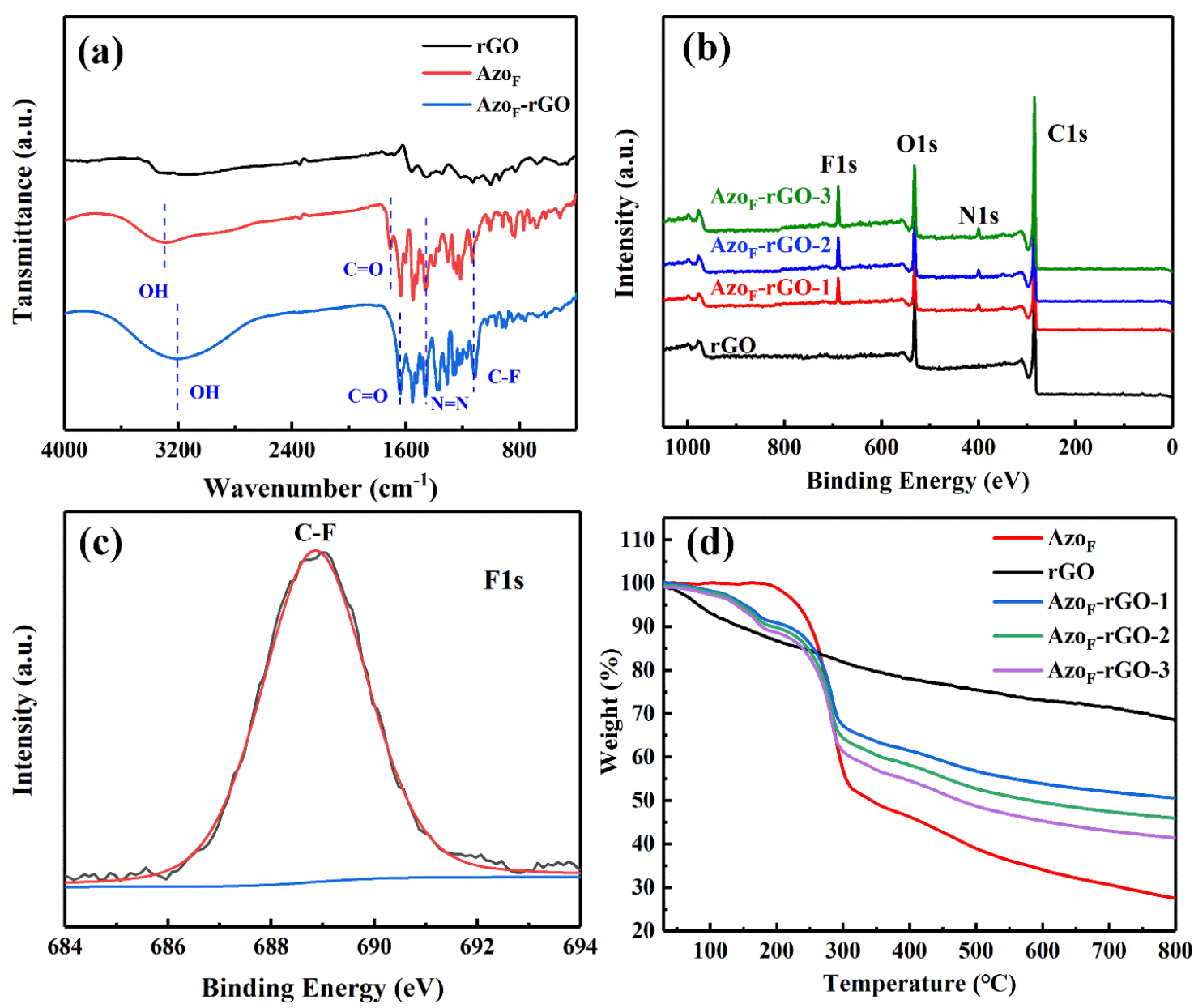

Figure 2. (a) FT-IR spectra of $\mathrm{rGO}, \mathrm{Azo}_{\mathrm{F}}$ and $\mathrm{Azo}_{\mathrm{F}}-\mathrm{rGO}$. (b) XPS spectra of $\mathrm{rGO}$ and Azo $-\mathrm{rGO}$. (c) F1s XPS spectra of $\mathrm{Azo}_{\mathrm{F}}-\mathrm{rGO}$. (d) TGA spectra of $\mathrm{rGO}, \mathrm{Azo}_{\mathrm{F}}$ and $\mathrm{Azo}_{\mathrm{F}}-\mathrm{rGO}$.

Table 1. $\mathrm{A}_{\mathrm{d}}$ of $\mathrm{Azo}_{\mathrm{F}}$ on rGO.

\begin{tabular}{|c|c|c|c|c|c|c|}
\hline \multirow{3}{*}{ Reaction Times } & \multicolumn{2}{|c|}{ TGA } & \multicolumn{4}{|c|}{ XPS } \\
\hline & \multirow{2}{*}{$D_{g}(\%)^{a}$} & \multirow{2}{*}{$\mathbf{A}_{\mathbf{d}}$} & \multicolumn{3}{|c|}{ Element Content (\%) } & \multirow{2}{*}{$\mathbf{A}_{\mathrm{d}}$} \\
\hline & & & C & F & O & \\
\hline $\mathrm{Azo}_{\mathrm{F}}-\mathrm{rGO}-1$ & 43.41 & $1: 40.1$ & 77.42 & 4.13 & 15.71 & $1: 40.2$ \\
\hline $\mathrm{Azo}_{\mathrm{F}}-\mathrm{rGO}-2$ & 52.95 & $1: 27.3$ & 74.13 & 5.09 & 17.39 & $1: 27.7$ \\
\hline $\mathrm{Azo}_{\mathrm{F}}-\mathrm{rGO}-3$ & 65.73 & $1: 16.0$ & 71.07 & 6.64 & 17.90 & $1: 16.1$ \\
\hline
\end{tabular}

${ }^{a} \mathrm{Dg}$ is the average weight percentage of $\mathrm{Azo}_{\mathrm{F}}$ in $\mathrm{AzO} \mathrm{F}_{\mathrm{F}}-\mathrm{rGO}$ at $600{ }^{\circ} \mathrm{C}, 700^{\circ} \mathrm{C}$ and $800{ }^{\circ} \mathrm{C}$.

\subsection{Cycling Stability and Storage Performance}

The optical properties performance of $\mathrm{Azo}_{\mathrm{F}}$ and $\mathrm{Azo}_{\mathrm{F}}-\mathrm{rGO}$ was investigated through time-evolved absorption spectra. It can be seen from Figure 3 that Azo $-\mathrm{rGO}$ went through a trans $\rightarrow$ cis isomerization process under $365 \mathrm{~nm}$ ultraviolet light irradiation. Compared with $\mathrm{Azo}_{\mathrm{F}}\left(\tau_{1 / 2}: 195.2 \mathrm{~min}\right), \mathrm{Azo}_{\mathrm{F}}-\mathrm{rGO}\left(\tau_{1 / 2}: 87.7 \mathrm{~h}\right)$ takes more time to complete the isomerization process from cis-isomer to trans-isomer, indicating that $\mathrm{Azo}_{\mathrm{F}}-\mathrm{rGO}$ has better thermal stability than pristine $\mathrm{Azo}_{\mathrm{F}}$. The same conclusion can be drawn from the fact that the 
first-order reversion rate constant $\left(K_{\text {rev }}\right)$ of $\mathrm{Azo}_{\mathrm{F}}-\mathrm{rGO}\left(3.29 \times 10^{-6} \cdot \mathrm{s}^{-1}\right)$ was much smaller than that of $\mathrm{Azo}_{\mathrm{F}}\left(1.20 \times 10^{-4} \cdot \mathrm{s}^{-1}\right)$ under dark conditions derived from Equation (2) [21].

$$
\ln \left(\frac{A_{t}-A_{\infty}}{A_{0}-A_{\infty}}\right)=-k_{\text {rev }} t
$$

where $A_{0}$ is the absorption intensity of $\mathrm{Azo}_{\mathrm{F}}-\mathrm{rGO}$ and $\mathrm{Azo}_{\mathrm{F}}$ at metastable state (cis-rich) irradiated by UV light, $A_{t}$ is the absorbance of $\mathrm{Azo}_{\mathrm{F}}-\mathrm{rGO}$ and $\mathrm{Azo}_{\mathrm{F}}$ reversing for " $t$ " time and $A_{\infty}$ is the absorption intensity of $\mathrm{Azo}_{\mathrm{F}}-\mathrm{rGO}$ and $\mathrm{Azo}_{\mathrm{F}}$ after complete cis-to-trans reversion. Moreover, compared to pristine $\mathrm{Azo}_{\mathrm{F}}$ (Figure S5), $\mathrm{Azo}_{\mathrm{F}}-\mathrm{rGO}$ exhibited a lower isomerization degree owing to the intermolecular H-bonds and steric hindrance owing to high attachment density, resulting in a better storage performance of this material. Furthermore, the $\Delta E a$ value of the $c i s$-isomer of $\mathrm{Azo}_{\mathrm{F}}-\mathrm{rGO}(1.05 \mathrm{eV})$ was higher than that of $\mathrm{Azo}_{\mathrm{F}}(0.94 \mathrm{eV})$ according to Equation (3) [42], which again proves the formation of intermolecular hydrogen bonds [43].

$$
E_{a}=-R \ln \frac{h \ln 2}{\tau_{1 / 2} k_{B} T}
$$

where $E_{a}$ is the activation barrier for cis-to-trans isomerization process, $T$ represents the temperature and $\tau_{1 / 2}$ represents the half-life. $k_{B}, R$ and $h$ are the Boltzman, universal gas and Plank constants. Additionally, the optical band gap of $\mathrm{Azo}_{\mathrm{F}}-\mathrm{rGO}$ complex was estimated to be $\sim 1.8 \mathrm{eV}$ based on the Tauc formula (Figure S6) [44]. The increase in the stability of the cis-isomer means extension of the life cycle of $\mathrm{Azo}_{\mathrm{F}}-\mathrm{rGO}$, which is directly related to the large-scale promotion of photoactive chemical heat storage materials.
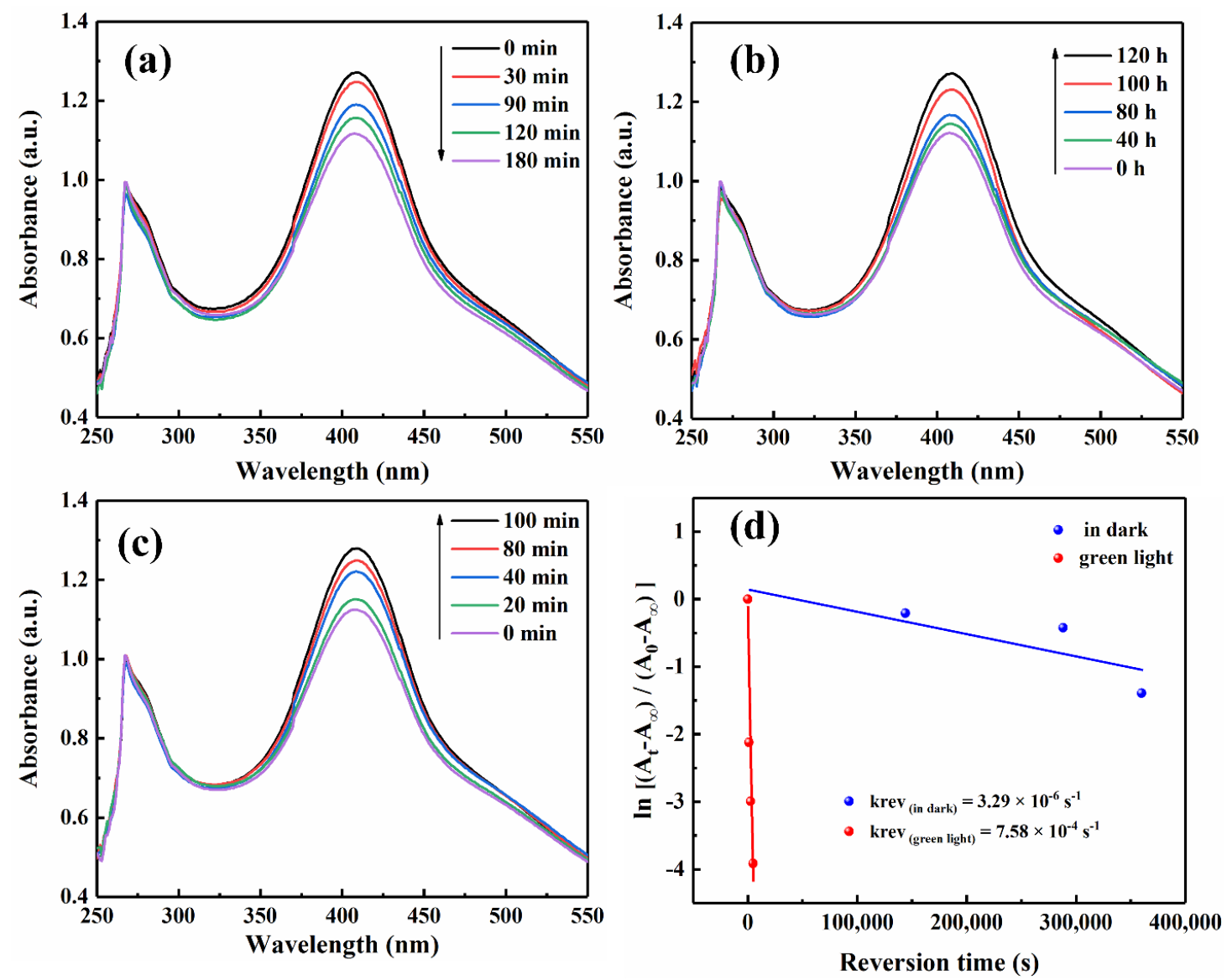

Figure 3. UV-Vis absorption spectra of Azo - -rGO-3 (a) under UV irradiation, (b) in dark conditions, (c) under visible light irradiation, (d) reversion rates curves of $\mathrm{Azo}_{\mathrm{F}}-\mathrm{rGO}$ in different environments. 
Similar to the length of the life cycle, whether the controllable heat release under external stimuli can be achieved is critical to the future application value of $\mathrm{Azo}_{\mathrm{F}}-\mathrm{rGO}$. Figure $3 \mathrm{c}$ showed that compared with dark conditions, the irradiation of green light $(540 \mathrm{~nm}) \mathrm{sig}$ nificantly accelerated the recovery process of $\mathrm{Azo}_{\mathrm{F}}-\mathrm{rGO}$ from cis -isomer to trans-isomer. Compared with dark conditions, the result that $K_{r e v}\left(7.58 \times 10^{-4} \cdot \mathrm{s}^{-1}\right)$ was significantly larger under green light irradiation also confirmed the conclusion of faster reversion. The same effect can also be achieved by absorbing heat from the external environment according to DSC. The reason for this phenomenon is that the cis-isomer can absorb energy from external stimuli to overcome the energy barrier of configuration reversion isomerization, thereby achieving the purpose of accelerating energy output $[45,46]$. The above results show that $\mathrm{Azo}_{\mathrm{F}}-\mathrm{rGO}$ has successfully possessed the controllable heat output capability.

The stability of repeated cis $\leftrightarrow$ trans configuration transformations of $\mathrm{Azo}_{\mathrm{F}}-\mathrm{rGO}$ and $\mathrm{Azo}_{\mathrm{F}}$ has also been studied. It can be seen from Figure 4 that both $\mathrm{Azo}_{\mathrm{F}}-\mathrm{rGO}$ and $\mathrm{Azo}_{\mathrm{F}}$ have no significant decrease in the absorption intensity at $407 \mathrm{~nm}$ after repeated irradiation of ultraviolet light $(365 \mathrm{~nm})$ and visible light $(540 \mathrm{~nm})$ for 50 times, which shows that they have outstanding isomerization stability. The $\mathrm{Azo}_{\mathrm{F}}-\mathrm{rGO}$ can not only be stored for a long time under the premise of ensuring the storage effect, but also can control the output of the stored energy, which is essential for actual photothermal conversion.
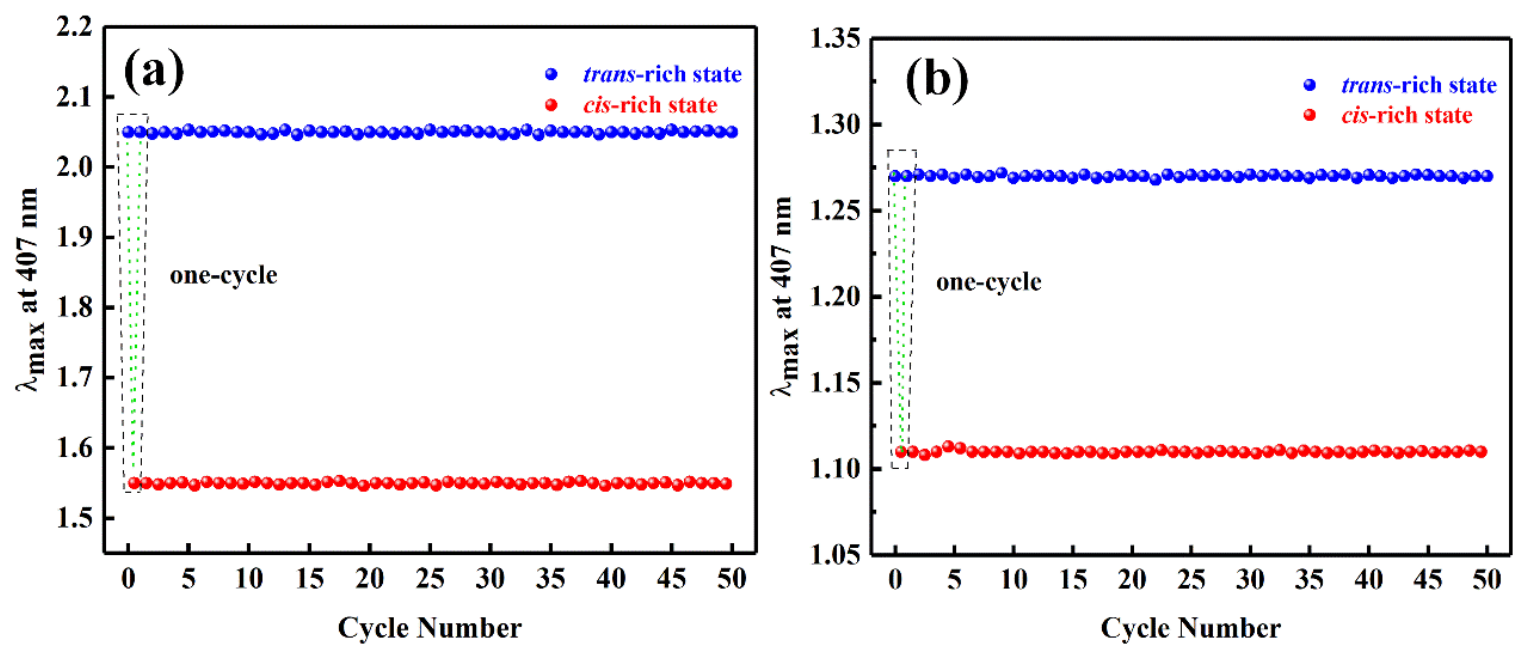

Figure 4. Stability performance of (a) $\mathrm{Azo}_{\mathrm{F}}$ and (b) $\mathrm{Azo}_{\mathrm{F}}-\mathrm{rGO}-3$ for 50 times.

The photothermal storage capacity of $\mathrm{Azo}_{\mathrm{F}}$ and $\mathrm{Azo}_{\mathrm{F}}-\mathrm{rGO}$ was investigated through DSC [7]. All objects were stable between $10-140{ }^{\circ} \mathrm{C}$ based on TGA. Azo ${ }_{F}$ and $\mathrm{Azo}_{\mathrm{F}}{ }^{-}$ rGO released significant heat under the first round of heating stimulation, but no heat was released during the second round according to Figure 5. The above results prove that the research subjects have released all the energy stored through the configuration transformation in the form of heat. Furthermore, most photothermal storage materials start to release the stored energy after $100{ }^{\circ} \mathrm{C}$, while this kind of heat storage material can start energy output at $35^{\circ} \mathrm{C}$, which is a milestone in achieving fast energy output at lower temperatures [7]. 

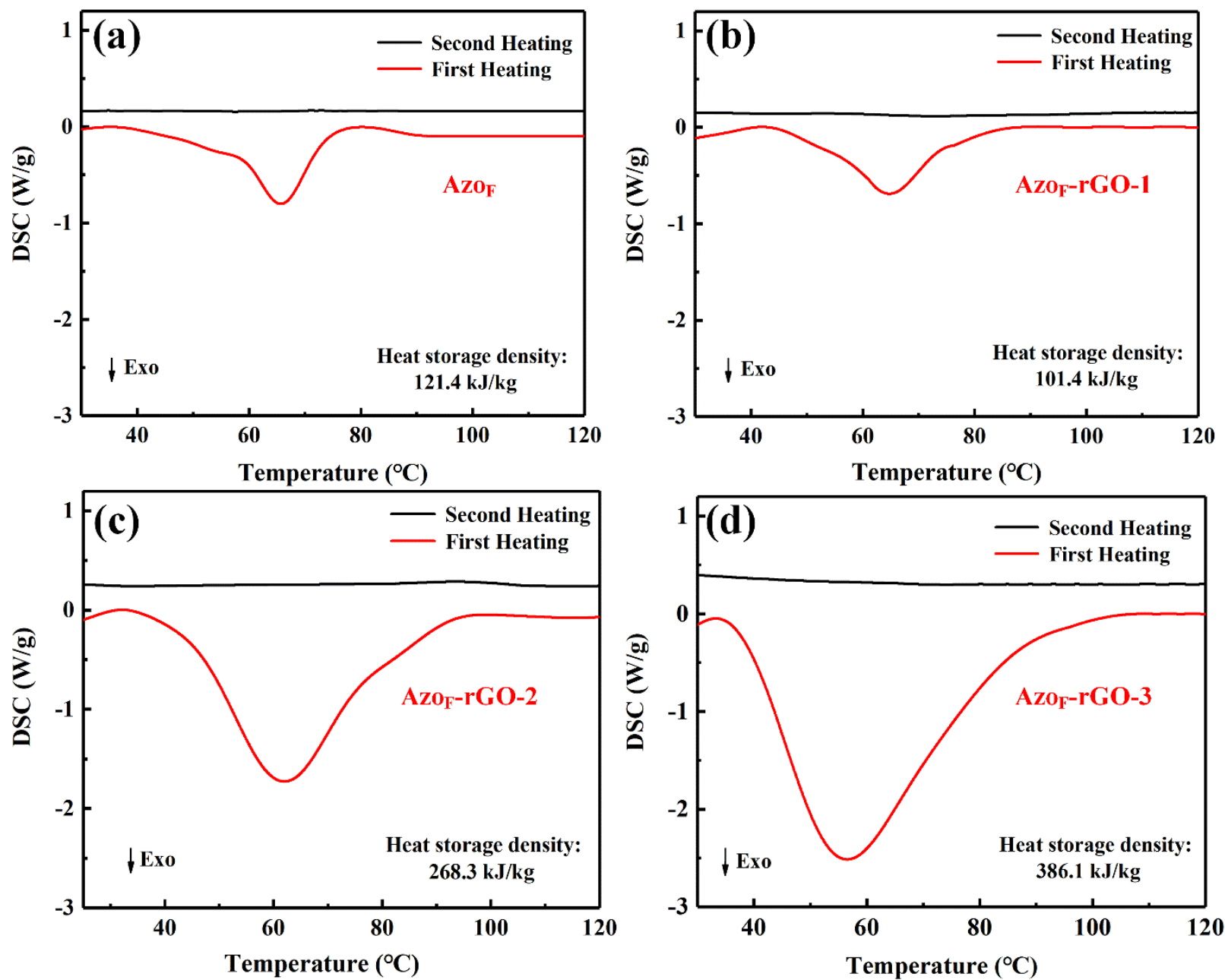

Figure 5. DSC (differential scanning calorimetry) traces of (a) Azo $\mathrm{F}$ and (b-d) $\mathrm{Azo}_{\mathrm{F}}$-rGO after 1, 2 and 3-times reaction.

It can be seen from Figure 5 that the heat storage density of $\mathrm{Azo}_{\mathrm{F}}-\mathrm{rGO}-3$ has reached to $386.1 \mathrm{~kJ} \mathrm{~kg}^{-1}$, which shows a significant increase over $\mathrm{Azo}_{\mathrm{F}}\left(121.4 \mathrm{~kJ} \mathrm{~kg}^{-1}\right)$. This is because of the close-packed orderly distribute of $\mathrm{Azo}_{\mathrm{F}}$ on $\mathrm{rGO}$ as a result of high attachment density, which strengthens the intermolecular interaction [23]. In addition, high attachment density also enhances the steric hindrance and promotes the formation of $\mathrm{H}$-bonds, which further increases the photothermal storage capacity [47]. The reason for $\mathrm{Azo}_{\mathrm{F}}-\mathrm{rGO}-1$ showing less effectiveness compared to the $\mathrm{Azo}_{\mathrm{F}}$ is the low attachment density, which leads to weak intermolecular interaction and therefore relatively low energy density. Moreover, the heat storage density of $\mathrm{Azo}_{\mathrm{F}}-\mathrm{rGO}-3$ was also higher than $\mathrm{Azo}_{\mathrm{F}}-\mathrm{rGO}-1$ and $\mathrm{Azo}_{\mathrm{F}}-\mathrm{rGO}-2$, which shows that the attachment density was positively correlated with great storage performance.

Similar to heat storage density, power density is also a key element to measure the possibility of practical application of $\mathrm{Azo}_{\mathrm{F}}-\mathrm{rGO}$. It can be seen from Figure 6 that the power density of $\mathrm{Azo}_{\mathrm{F}}-\mathrm{rGO}-3$ was $890.6 \mathrm{~W} \mathrm{~kg}^{-1}$, which shows a huge improvement compared to $\mathrm{Azo}_{\mathrm{F}}\left(448.6 \mathrm{~W} \mathrm{~kg}^{-1}\right)$. Furthermore, the power density of Azo $-\mathrm{rGO}-3$ was also higher than Azo $_{\mathrm{F}}-\mathrm{rGO}-1$ and $\mathrm{Azo}_{\mathrm{F}}-\mathrm{rGO}-2$, which shows that the attachment density is directly related to the heat output performance. It is worth noting that high power density means fast output of energy, which further increases the feasibility of practical application of $\mathrm{Azo}_{\mathrm{F}}-\mathrm{rGO}$. As shown in Table 2, the performance of $\mathrm{Azo}_{\mathrm{F}}-\mathrm{rGO}$ in many aspects has been greatly improved compared to other similar materials $[7,15,48,49]$. The above results demonstrate that $\mathrm{Azo}_{\mathrm{F}}-$ rGO, which not only exhibits remarkable photothermal capacity but also equipped with 
low temperature energy output capability, has shown great development potential in achieving the goal of efficient photothermal storage.

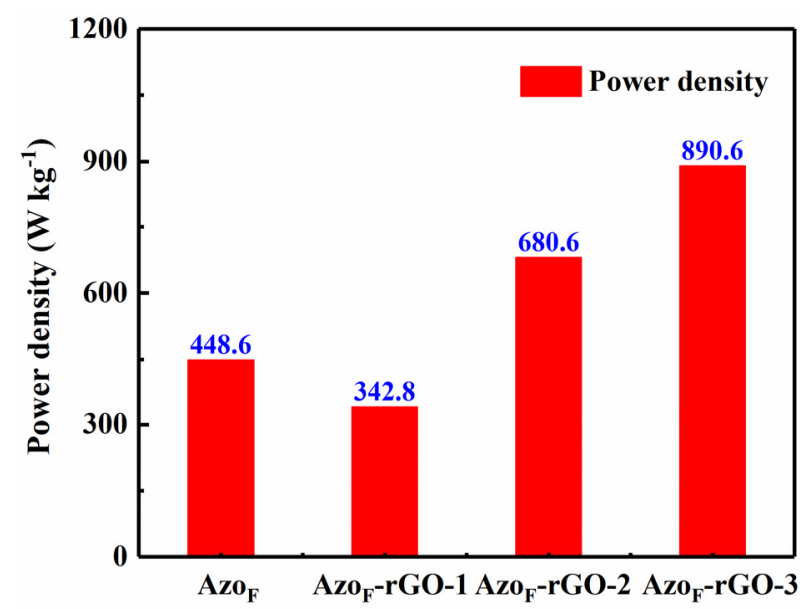

Figure 6. Power density of $\mathrm{Azo}_{\mathrm{F}}$ and $\mathrm{Azo}_{\mathrm{F}}-\mathrm{rGO}$ after 1, 2 and 3-times reaction.

Table 2. Performance of different photothermal conversion materials.

\begin{tabular}{|c|c|c|c|c|}
\hline $\begin{array}{c}\text { Photothermal } \\
\text { Conversion Material }\end{array}$ & $\begin{array}{l}\text { Energy Density } \\
\quad\left(\mathrm{kJ} \mathrm{mol}{ }^{-1}\right)\end{array}$ & $\begin{array}{l}\text { Power Density } \\
(\mathrm{W} \mathrm{mol}-1)\end{array}$ & Half-Life (h) & Ref. \\
\hline $\begin{array}{l}\text { Azo-diacetylene } \\
\text { polymer }\end{array}$ & 176.2 & 1289.5 & 27.8 & [48] \\
\hline Azo-SWCNT complex & 92.0 & 457.1 & 0.5 & [7] \\
\hline Azo-PCM complex & 79.3 & - & - & [15] \\
\hline Azo-alkyl polymer & 89.0 & 148.6 & 55 & [49] \\
\hline Azo $_{\mathrm{F}}-\mathrm{rGO}-3$ complex & 367.7 & 848.6 & 87.7 & This paper \\
\hline
\end{tabular}

\section{Conclusions}

In summary, $\mathrm{Azo}_{\mathrm{F}}-\mathrm{rGO}$ with good photothermal storage performance, outstanding storage lifespan and low-temperature energy output capability has been proven to be a great photothermal conversion material. The formation of hydrogen bonds and the enhancement of intermolecular interactions owing to the high attachment density has simultaneously achieved the improvement of the heat storage density (max. $386.1 \mathrm{~kJ} \mathrm{~kg}^{-1}$ ), power density (max. $890.6 \mathrm{~W} \mathrm{~kg}^{-1}$ ) and half-life (up to $87.7 \mathrm{~h}$ ) of $\mathrm{Azo}_{\mathrm{F}}-\mathrm{rGO}$ for photothermal storage. $\mathrm{Azo}_{\mathrm{F}}-\mathrm{rGO}$ also exhibits exceptional cycling stability, which realizes long-term recyclability and efficient and pollution-free utilization of solar energy in a closed system. Furthermore, $\mathrm{Azo}_{\mathrm{F}}-\mathrm{rGO}$ can start energy output at $35^{\circ} \mathrm{C}$, which shows that the goal of low-temperature energy output has been achieved. The above results indicate that $\mathrm{Azo}_{\mathrm{F}}-\mathrm{rGO}$, combining outstanding photothermal capacity with a long-life cycle as well as low-temperature energy output capability, is a prominent photothermal conversion material with great practical application value.

Supplementary Materials: The following are available online at https:/ / www.mdpi.com/1996-1 944/14/6/1434/s1, Figure S1: ${ }^{1} \mathrm{H}$ NMR, ${ }^{13} \mathrm{C}$ NMR and ${ }^{19} \mathrm{~F}$ NMR spectra of Azo , Figure S2: XRD patterns of GO, rGO, Azo ${ }_{\mathrm{F}}-\mathrm{rGO}$, Figure S3: C1s region in XPS spectra of (a) rGO, (b) Azo $-\mathrm{rGO}$ and (c) N1s region in XPS spectra, Figure S4: Raman spectra, Figure S5: Time-evolved absorption spectra of $\mathrm{Azo}_{\mathrm{F}}$ and Figure S6: UV-Vis absorption spectra of $\mathrm{Azo}_{\mathrm{F}}-\mathrm{rGO}$ powder at room temperature $\left(25^{\circ} \mathrm{C}\right)$.

Author Contributions: Conceptualization, X.Y. and S.L.; methodology, X.Y.; software, X.Y.; validation, X.W. and Y.W.; formal analysis, X.Y.; investigation, X.Y.; resources, J.Z. (Jin Zhang); data curation, X.Y. and S.L.; writing-original draft preparation, X.Y.; writing-review and editing, S.L.; visualization, J.Z. (Jianguo Zhao); supervision, J.Z. (Jin Zhang); project administration, J.Z. (Jianguo 
Zhao); funding acquisition, J.Z. (Jin Zhang). All authors have read and agreed to the published version of the manuscript.

Funding: This research was funded by National Natural Science Foundation of China (Grant No. 52071192), Shanxi "1331 project" foundation for the construction of collaborative innovation center of graphene industrial application, Key Research and Development Project of Shanxi Province (Grant No. 201803D121122), Research and development projects in key areas of Guangdong Province (Grant No. 2020B0202010004), The Program for Scientific and Technological Innovation of Higher Education Institutions in Shanxi (Grant No. 2020L0477).

Institutional Review Board Statement: Not applicable.

Informed Consent Statement: Not applicable.

Data Availability Statement: The data presented in this study are available in [insert article or Supplementary Material].

Conflicts of Interest: The authors declare no conflict of interest.

\section{References}

1. Armaroli, N.; Balzani, V. The future of energy supply: Challenges and opportunities. Angew. Chem. Int. Ed. Engl. 2007, 46, 52-66. [CrossRef] [PubMed]

2. Zhang, X.; Peng, T.; Song, S. Recent advances in dye-sensitized semiconductor systems for photocatalytic hydrogen production. J. Mater. Chem. A 2016, 4, 2365-2402. [CrossRef]

3. Aguirre, M.E.; Zhou, R.; Eugene, A.J.; Guzman, M.I.; Grela, M.A. Cu2O/TiO2 heterostructures for CO2 reduction through a direct Z-scheme: Protecting Cu2O from photocorrosion. Appl. Catal. B Environ. 2017, 217, 485. [CrossRef]

4. Zhou, R.; Guzman, M.I. CO2 Reduction under Periodic Illumination of ZnS. J. Phys. Chem. C 2015, 118, 11649-11656. [CrossRef]

5. Moth-Poulsen, K.; Ćoso, D.; Börjesson, K.; Vinokurov, N.; Meier, S.K.; Majumdar, A.; Vollhardt, K.P.C.; Segalman, R.A. Molecular solar thermal (MOST) energy storage and release system. Energy Environ. Sci. 2012, 5, 8534-8537. [CrossRef]

6. Yoshida, Z.-I. New molecular energy storage systems. J. Photochem. 1985, 29, 27-40. [CrossRef]

7. Kucharski, T.J.; Ferralis, N.; Kolpak, A.M.; Zheng, J.O.; Nocera, D.G.; Grossman, J.C. Templated assembly of photoswitches significantly increases the energy-storage capacity of solar thermal fuels. Nature Chem. 2014, 6, 441-447. [CrossRef] [PubMed]

8. Kanai, Y.; Srinivasan, V.; Meier, S.K.; Vollhardt, K.P.; Grossman, J.C. Mechanism of thermal reversal of the (fulvalene)tetracarbonyldiruthenium photoisomerization: Toward molecular solar-thermal energy storage. Angew. Chem. Int. Ed. Engl. 2010, 49, 8926-8929. [CrossRef]

9. Berthiller, F.; Dall'asta, C.; Corradini, R.; Marchelli, R.; Sulyok, M.; Krska, R.; Adam, G.; Schuhmacher, R. Occurrence of deoxynivalenol and its 3-beta-D-glucoside in wheat and maize. Food Addit. Contam. Part A Chem. Anal. Control. Expo. Risk Assess 2009, 26, 507-511. [CrossRef]

10. Lee, K.M.; Smith, M.L.; Koerner, H.; Tabiryan, N.; Vaia, R.A.; Bunning, T.J.; White, T.J. Photodriven, Flexural-Torsional Oscillation of Glassy Azobenzene Liquid Crystal Polymer Networks. Adv. Funct. Mater. 2011, 21, 2913-2918. [CrossRef]

11. Liu, J.; Bu, W.; Pan, L.; Shi, J. NIR-triggered anticancer drug delivery by upconverting nanoparticles with integrated azobenzenemodified mesoporous silica. Angew. Chem. Int. Ed. Engl. 2013, 52, 4375-4379. [CrossRef] [PubMed]

12. Sun, L.; Gao, F.; Shen, D.; Liu, Z.; Yao, Y.; Lin, S. Rationally designed hyperbranched azopolymer with temperature, photo and pH responsive behavior. Polym. Chem. 2018, 9, 2977-2983. [CrossRef]

13. Wang, G.; Yuan, D.; Yuan, T.; Dong, J.; Feng, N.; Han, G. A visible light responsive azobenzene-functionalized polymer: Synthesis, self-assembly, and photoresponsive properties. J. Polym. Sci. Part A Polym. Chem. 2015, 53, 2768-2775. [CrossRef]

14. Iii, J.O.; Lawrence, J.; Yee, G.G. Photochemical storage potential of azobenzenes. Sol. Energy 1983, 30, $271-274$.

15. Han, G.G.D.; Li, H.; Grossman, J.C. Optically-controlled long-term storage and release of thermal energy in phase-change materials. Nat. Commun. 2017, 8, 1446. [CrossRef]

16. Joshi, D.K.; Mitchell, M.J.; Bruce, D.; Lough, A.J.; Yan, H. Synthesis of cyclic azobenzene analogues. Tetrahedron 2012, 68, 8670-8676. [CrossRef]

17. Weston, C.E.; Richardson, R.D.; Haycock, P.R.; White, A.J.; Fuchter, M.J. Arylazopyrazoles: Azoheteroarene photoswitches offering quantitative isomerization and long thermal half-lives. J. Am. Chem. Soc. 2014, 136, 11878-11881. [CrossRef]

18. Cho, E.N.; Zhitomirsky, D.; Han, G.G.; Liu, Y.; Grossman, J.C. Molecularly Engineered Azobenzene Derivatives for High Energy Density Solid-State Solar Thermal Fuels. ACS Appl. Mater. Interfaces 2017, 9, 8679-8687. [CrossRef]

19. Bleger, D.; Schwarz, J.; Brouwer, A.M.; Hecht, S. o-Fluoroazobenzenes as readily synthesized photoswitches offering nearly quantitative two-way isomerization with visible light. J. Am. Chem. Soc. 2012, 134, 20597-20600. [CrossRef]

20. Lennartson, A.; Roffey, A.; Moth-Poulsen, K. Designing photoswitches for molecular solar thermal energy storage. Tetrahedron Lett. 2015, 56, 1457-1465. [CrossRef]

21. Feng, Y.; Liu, H.; Luo, W.; Liu, E.; Zhao, N.; Yoshino, K.; Feng, W. Covalent functionalization of graphene by azobenzene with molecular hydrogen bonds for long-term solar thermal storage. Sci. Rep. 2013, 3, 3260. [CrossRef] 
22. Kurihara, S.; Nomiyama, S.; Nonaka, T. Photochemical control of the macrostructure of cholesteric liquid crystals by means of photoisomerization of chiral azobenzene molecules. Chem. Mater. 2001, 13, 1992-1997. [CrossRef]

23. Kolpak, A.M.; Grossman, J.C. Hybrid chromophore/template nanostructures: A customizable platform material for solar energy storage and conversion. J. Chem. Phys. 2013, 138, 034303. [CrossRef]

24. Wu, J.; Yang, Y.; Qu, Y.; Jia, L.; Zhang, Y.; Xu, X.; Chu, S.T.; Little, B.E.; Morandotti, R.; Jia, B.; et al. 2D Layered Graphene Oxide Films Integrated with Micro-Ring Resonators for Enhanced Nonlinear Optics. Small 2020, 16, 1906563. [CrossRef]

25. Wu, J.; Yang, Y.; Qu, Y.; Xu, X.; Liang, Y.; Chu, S.T.; Little, B.E.; Morandotti, R.; Jia, B.; Moss, D.J. Graphene Oxide Waveguide and Micro-Ring Resonator Polarizers. Laser Photonics Rev. 2019, 13, 1900056. [CrossRef]

26. Wu, S.; Butt, H.-J. Solar-Thermal Energy Conversion and Storage Using Photoresponsive Azobenzene-Containing Polymers. Macromol. Rapid Commun. 2020, 41, 1900413. [CrossRef] [PubMed]

27. Zhang, X.; Feng, Y.; Huang, D.; Li, Y.; Feng, W. Investigation of optical modulated conductance effects based on a graphene oxide-azobenzene hybrid. Carbon 2010, 48, 3236-3241. [CrossRef]

28. Wang, Z.; Li, Z.-x.; Liu, Z. Photostimulated reversible attachment of gold nanoparticles on multiwalled carbon nanotubes. J. Phys. Chem. C 2009, 113, 3899-3902. [CrossRef]

29. Hummers, W.S.; Offeman, R.E. Preparation of Graphitic Oxide. J. Am. Chem. Soc. 1958, 80, 1339. [CrossRef]

30. An, X.; Simmons, T.J.; Shah, R.; Wolfe, C.S.; Lewis, K.M.; Washington, M.; Nayak, S.K.; Talapatra, S.; Kar, S. Stable Aqueous Dispersions of Noncovalently Functionalized Graphene from Graphite and their Multifunctional High-Performance Applications. Nano Lett. 2010, 10, 4295-4301. [CrossRef]

31. Englert, J.M.; Dotzer, C.; Yang, G.; Schmid, M.; Papp, C.; Gottfried, J.M.; Steinruck, H.; Spiecker, E.; Hauke, F.; Hirsch, A. Covalent bulk functionalization of graphene. Nat. Chem. 2011, 3, 279-286. [CrossRef] [PubMed]

32. Marcano, D.C.; Kosynkin, D.V.; Berlin, J.M.; Sinitskii, A.; Sun, Z.; Slesarev, A.; Alemany, L.B.; Lu, W.; Tour, J.M. Improved Synthesis of Graphene Oxide. ACS Nano 2010, 4, 4806-4814. [CrossRef] [PubMed]

33. Lim, D.J.; Marks, N.A.; Rowles, M.R. Universal Scherrer equation for graphene fragments. Carbon 2020, 162, 475-480. [CrossRef]

34. Li, D.; Muller, M.B.; Gilje, S.; Kaner, R.B.; Wallace, G.G. Processable aqueous dispersions of graphene nanosheets. Nat. Nanotechnol. 2008, 3, 101-105. [CrossRef]

35. Min, M.; Bang, G.S.; Lee, H.; Yu, B. A photoswitchable methylene-spaced fluorinated aryl azobenzene monolayer grafted on silicon. Chem. Commun. 2010, 46, 5232-5234. [CrossRef]

36. Gearba, R.I.; Lehmann, M.; Levin, J.; Ivanov, D.A.; Koch, M.H.J.; Barbera, J.; Debije, M.G.; Piris, J.; Geerts, Y. Tailoring discotic mesophases: Columnar order enforced with hydrogen bonds. Adv. Mater. 2003, 15, 1614-1618. [CrossRef]

37. Zhang, X.; Feng, Y.; Lv, P.; Shen, Y.; Feng, W. Enhanced reversible photoswitching of azobenzene-functionalized graphene oxide hybrids. Langmuir 2010, 26, 18508-18511. [CrossRef]

38. Zhang, B.; Zhang, Y.; Peng, C.; Yu, M.; Li, L.; Deng, B.; Hu, P.; Fan, C.; Li, J.; Huang, Q. Preparation of polymer decorated graphene oxide by $\gamma$-ray induced graft polymerization. Nanoscale 2012, 4, 1742-1748. [CrossRef]

39. Yu, D.S.; Kuila, T.; Kim, N.H.; Khanra, P.; Lee, J.H. Effects of covalent surface modifications on the electrical and electrochemical properties of graphene using sodium 4-aminoazobenzene-4'-sulfonate. Carbon 2013, 54, 310-322. [CrossRef]

40. Kim, M.; Safron, N.S.; Huang, C.; Arnold, M.S.; Gopalan, P. Light-driven reversible modulation of doping in graphene. Nano Lett. 2012, 12, 182-187. [CrossRef] [PubMed]

41. Bandara, H.M.D.; Burdette, S.C. Photoisomerization in different classes of azobenzene. Chem. Soc. Rev. 2012, 41, 1809-1825. [CrossRef]

42. Samanta, S.; Beharry, A.A.; Sadovski, O.; Mccormick, T.M.; Babalhavaeji, A.; Tropepe, V.; Woolley, G.A. Photoswitching azo compounds in vivo with red light. J. Am. Chem. Soc. 2013, 135, 9777-9784. [CrossRef] [PubMed]

43. Kolpak, A.M.; Grossman, J.C. Azobenzene-Functionalized Carbon Nanotubes As High-Energy Density Solar Thermal Fuels. Nano Lett. 2011, 11, 3156-3162. [CrossRef] [PubMed]

44. Zhang, G.; Amani, M.; Chaturvedi, A.; Tan, C.; Bullock, J.; Song, X.; Kim, H.; Lien, D.H.; Scott, M.C.; Zhang, H. Optical and electrical properties of two-dimensional palladium diselenide. Appl. Phys. Lett. 2019, 114, 253102. [CrossRef]

45. Yang, Y.; Hughes, R.P.; Aprahamian, I. Visible Light Switching of a BF2-Coordinated Azo Compound. J. Am. Chem. Soc. 2012, 134, 15221-15224. [CrossRef]

46. Siewertsen, R.; Neumann, H.; Buchheimstehn, B.; Herges, R.; Nather, C.; Renth, F.; Temps, F. Highly Efficient Reversible Z-E Photoisomerization of a Bridged Azobenzene with Visible Light through Resolved S1(n $\left.\pi^{*}\right)$ Absorption Bands. J. Am. Chem. Soc. 2009, 131, 15594-15595. [CrossRef]

47. Liu, Y.; Grossman, J.C. Accelerating the Design of Solar Thermal Fuel Materials through High Throughput Simulations. Nano Lett. 2014, 14, 7046-7050. [CrossRef] [PubMed]

48. Han, G.D.; Park, S.S.; Liu, Y.; Zhitomirsky, D.; Cho, E.; Dincă, M.; Grossman, J.C. Photon energy storage materials with high energy densities based on diacetylene-azobenzene derivatives. J. Mater. Chem. A 2016, 4, 16157-16165. [CrossRef]

49. Zhitomirsky, D.; Cho, E.; Grossman, J.C. Solid-State Solar Thermal Fuels for Heat Release Applications. Adv. Energy Mater. 2016, 6,1502006 . [CrossRef] 